\title{
ARTICLES
}

Submitted 12.01.2019. Approved 07.29.2020

Evaluated through a double-blind review process. Scientific Editor: Mateus Canniatti Ponchio

Original version | DOI: http://dx.doi.org/10.1590/So034-759020210404

\section{DESIGNING ARCHITECTURAL MARIKETING CAPABILITIES TO INCREASE THE PERFORMANCE OF SMALL AND MEDIUM-SIZED ENTERPRISES}

\author{
Desenvolvendo os componentes da orientação para o mercado para melhorar o desempenho de \\ pequenas e médias empresas \\ Diseño de capacidades de marketing arquitectónico para aumentar el rendimiento de pequeñas \\ y medianas empresas
}

Mulyana Mulyana ${ }^{1}$ mulyana@unissula.ac.id | ORCID: 0000-0002-7887-5195

Zainuddin Zakaria² | hzainudd@uitm.edu.my | ORCID: 0000-0003-4907-402X Rosman Mahmood² | rosmanma@uitm.edu.my | ORCID: 00oo-0o03-3316-1727

1 Universitas Islam Sultan Agung, Department of Management Science, Faculty of Economics, Semarang, Indonesia ${ }^{2}$ Universiti Teknologi MARA, Faculty of Business and Management, Dungun, Terengganu, Malaysia

\begin{abstract}
This study aims to examine the relationship between the components of market orientation, i.e., customer orientation, competitor orientation, inter-functional coordination, architectural marketing capabilities and business performance. Researchers have been trying to find a solution for the gap that exists between market orientation and business performance. The respondents of this study were the owners or heads of 358 SMEs located in Central Java, Indonesia. This study used structural equation modeling (SEM) for data analysis. The results showed that customer orientation (CSO), competitor orientation (CO), and inter-functional coordination (IC) have a significant effect on architectural marketing capabilities (AMC) and business performance (BP), and that AMC also has a significant effect on business performance. Furthermore, architectural marketing capabilities can mediate the relationship between customer orientation, competitor orientation, inter-functional coordination and business performance.
\end{abstract}

KEYWORDS | Customer orientation, competitor orientation, inter-functional coordination, architectural marketing capabilities, business performance

\section{RESUMO}

Este estudo tem como objetivo examinar a relação entre os componentes da orientação para o mercado - orientação para o cliente, orientação para a concorrência, coordenação interfuncional e capacidades de arquitetura de marketing - e o desempenho da empresa. Pesquisadores vêm tentando encontrar uma solução para a lacuna existente entre a orientação para o mercado e o desempenho da empresa. Os sujeitos deste estudo foram 358 proprietários ou gestores de pequenas e médias empresas (PMEs) em Java Central, na Indonésia. A pesquisa utilizou Modelagem de Equações Estruturais (SEM) para analisar os dados. Os resultados mostraram que a Orientação para o Cliente (OCL), a Orientação para Concorrência (OC) e a Coordenação Interfuncional (CI) tiveram uma influência significativa nas Capacidades de Arquitetura de Marketing (CAM) e no Desempenho da Empresa (DE), e que as CAM também tiveram uma influência significativa no desempenho da empresa. Além disso, as CAM podem mediar a relação entre a orientação para o cliente, a orientação para a concorrência, a coordenação interfuncional e o desempenho da empresa.

PALAVRAS-CHAVE I Orientação para o cliente, orientação para a concorrência, coordenação interfuncional, capacidades de arquitetura de marketing, desempenho da empresa.

\section{RESUMEN}

Este estudio tiene como objetivo determinar el efecto de los componentes de orientación del mercado, a saber, la orientación al cliente, la orientación a la competencia, la coordinación entre funciones y recursos de marketing arquitectónico en el rendimiento del negocio. Los investigadores están tratando de encontrar una solución para la brecha que existe entre la orientación al mercado y el desempeño comercial. Los encuestados de este estudio fueron 358 propietarios o líderes de pymes en Java Central, Indonesia. Esta investigación utilizó el modelado de ecuaciones estructurales (SEM) como análisis de datos. Los resultados mostraron que la orientación al cliente (CSO), la orientación a la competencia (CO) y la coordinación interfuncional (IC) tuvieron una influencia significativa en la capacidad de marketing arquitectónico (AMC) y en el desempeño comercial (BP). Asimismo, la AMC tuvo una influencia significativa en el desempeño comercial. Además, las capacidades de marketing arquitectónico pueden mediar la relación entre la orientación al cliente, la orientación a la competencia, la coordinación interfuncional y el rendimiento empresarial.

PALABRAS CLAVE I Orientación al cliente, orientación a la competencia, coordinación funcional, habilidades de marketing arquitectónico, desempeño comercial. 


\section{INTRODUCTION}

Research has already been conducted into the relationship between market orientation and business performance. Market orientation was initially introduced as a component affecting business performance (Dubihlela \& Sandada, 2014; Kaswuri, 2017). The study of the relationship between market orientation components (customer orientation, competitor orientation, and inter-functional coordination) and business performance is expected to provide comprehensive results in the field of management. The results of previous studies show that market orientation is the key to success for delivering business performance (Udriyah, Tham, \& Azam, 2019). While some studies explain that market orientation has a contribution to play in improving business performance (Herman, Hady, \& Arafah, 2018; Hwang \& Chung, 2018; Mamun, Mohiuddin, Fazal, \& Ahmad, 2018), other studies show different results ; that there is no relationship between market orientation and business performance (Gholami \& Birjandi, 2016; Idrus, Ahmar, \& Abdussakir, 2018). Market orientation is also unable to improve financial performance (Ho, Nguyen, Adhikari, Miles, \& Bonney, 2018), and companies that are always proactive in market orientation have been unable to deliver superior business performance (Kharabsheh, Jarrar, \& Simenonva, 2014).

Customer orientation, competitor orientation, and inter-functional coordination are components of market orientation, which is a set of organizational cultural behaviors (Slater \& Narver, 1990). Customer orientation as a behavior of the organizational culture is expected to be able to understand customer needs and demands. Competitor orientation is expected to understand competitors' strengths, weaknesses, and strategies, while inter-functional coordination is expected to build harmonious relationships between functions in order to seize market opportunities. It is expected that the ability to understand market orientation components will facilitate the planning and implementation of marketing.

The development of architectural marketing capabilities is a process that includes planning and implementing marketing strategies (Morgan, 2012). Marketing needs to be planned in order to set market targets and develop effective marketing strategies, while implementation of a marketing process is needed to facilitate the allocation of marketing resources, interpret marketing strategies appropriately and effectively introduce marketing programs (Vorhies \& Morgan, 2005). Little research has been conducted into the effect of market orientation on architectural marketing capabilities. Sometimes market orientation and architectural marketing capabilities are treated as independent variables that affect company performance (Morgan, Slotegraaf, \& Vorhies, 2009). Likewise, understanding the relationship between business performance and market orientation will be more complete if the objectives are understood, so the role of the mediator will determine the strength of the relationship (Han, Kim, Han, Kim, \& Srivastava, 1998).

Differences in the above research findings may be the result of inappropriate measurements, the improper placement of mediators, or because of the various data collection or analysis techniques used. Because of this research gap, there are still opportunities for further research, and this study aims to fill the gap between the components of market orientation and business performance. It will do so by employing architectural marketing capabilities as a mediator variable. A detailed understanding of the relationship between architectural marketing capabilities, market orientation components, and business performance is still needed to increase the wealth of science being developed, especially in the field of marketing management. 


\section{THEORETICAL BACKGROUND}

\section{The conceptual development of architectural marketing capabilities}

The resource-based view (RBV) states that capabilities are a resource that, if properly managed, will be an advantage in the company (Barney, 1991). Capabilities are a company's ability to exploit the resources it has (Javidan, 1998). Capabilities can be developed if individuals and groups are able to explore their knowledge and skills to support the achievement of company goals (Morgan, 2012).

Architectural capabilities refer to the process of selecting, integrating and managing special abilities and sharing resources between functions in an organization (Galunic \& Rodan, 1998; Henderson \& Clark, 1990). Architectural marketing includes the process of setting marketing objectives, formulating marketing strategies (Slotegraaf \& Dickson, 2004; Vorhies \& Morgan, 2003) and implementing marketing strategy decisions supported by company resources (Capron \& Hulland, 1999; Vorhies \& Morgan, 2005).

Marketing capabilities are the integrative process that is designed to apply knowledge, skills and company resources for meeting the needs of target markets (Day, 1994; Hamdani, Susanto, \& Maulani, 2018). In this study, architectural marketing capabilities are the ability to manage resources for planning and implementing marketing plans in order to reach target markets, as measured by the indicators of the skills employed in market planning, developing creative marketing strategies, accuracy in choosing target markets, allocating marketing resources effectively, interpreting marketing strategies and turning them into action, and appropriately running marketing strategies.

\section{Market orientation}

According to Slater and Narver (1990), the study of the components of market orientation, which include customers, competitor orientation, and inter-functional coordination, is part of the market-oriented organizational. Customer orientation should be able to understand target buyers sufficiently over time in order to create customer value. Competitor orientation should obtain information on both key and potential competitors and understand the strengths and weaknesses of short-term and long-term competitors. Interfunctional coordination is useful for coordinating resources to create superior value for the target market. Studies of market orientation in the context of marketing recognize the role of corporate culture in influencing market orientation. They also introduce other sides that are useful for theory testing, benchmarking and tracking (Kohli \& Jaworski, 1993). Market orientation involves customers and competitors, recognizes the role of organizational culture in supporting market orientation, and recognizes market orientation as the basis for corporate strategy. Market-oriented companies can develop and disseminate specific and distinctive marketing capabilities to differentiate themselves from competing companies. Market research, pricing, product development, distribution channels, promotion, and market management are needed to strengthen corporate marketing capabilities (Vorhies, Harker, \& Rao, 1999). Market orientation can increase marketing implementation capabilities, which in turn strengthen business performance that focuses on customers, namely on attracting and retaining them. 


\section{Business performance}

According to Rahman et al. (2018), the method used for measuring business performance is multidimensional vis-à-vis the desired subject. Some researchers use growth dimension as a proxy for business performance (Cho \& Pucik, 2005; Morgan et al., 2009). According to Stam, Arzlanian, and Elfring (2014), business performance in small businesses can be explained in terms of three dimensions, namely growth performance, profitability, and non-financial performance. Lee, Kim, Seo, and Hight (2015) define business performance as the company's achievements, including its financial and non-financial performance. Financial performance is measured by the respondents' perceptions with regard to achieving their net profit and sales goals, increasing net income and sales and reaching the planed-for number of contracts. Non-financial performance is measured by indicators of the respondents' perceptions for improving their new product and service capabilities, and increasing employee and customer satisfaction. Due to poor governance in SMEs, respondents' perceptions are used as an approach to measure business performance. Business performance is the result of the organization's operational activities, which include internal and external results as measured by the ROA, sales growth, growth in market share and growth in profit (Nuryakin, Didiek, \& Budi, 2018). In this study, business performance is the company's ability to achieve its financial and marketing objectives, as measured by indicators of the growth in sales results, the increase in the number of customers, expansion of the sales areas, profit growth, and growth in business capital.

\section{CONCEPTUAL FRAMEWORK AND RESEARCH HYPOTHESES}

\section{Customer orientation and architectural marketing capabilities}

Customer orientation is the company's ability to observe and evaluate trends in its customers' needs, which encourages the company to innovate in terms of its products and services in order to satisfy these customers (Micheels \& Gow, 2008; Sadikoglu \& Zehir, 2010). Knowledge of the market is very useful for guiding the planning of marketing that is in harmony with environmental changes (Moorman \& Slotegraaf, 1999). A company's resources will be used to develop a marketing strategy (Davcik \& Sharma, 2016), which include knowledge, financial capacity, human resources, networking, information and development (Hamdani et al., 2018). Other studies show that marketing resources in the form of knowledge, information and human resources can be used as a basis for developing marketing strategies (Foumani \& Chirani, 2012). Companies that understand their customers' needs, create added value, and provide after-sales services, will be better equipped for re-arranging their marketing resources. Therefore, the ability of marketing resources to understand customers thoroughly enables companies to improve their ability to plan and implement their marketing initiatives.

$\mathrm{H}_{1}$ : There is a positive and significant relationship between CSO and AMC

\section{Competitor orientation and architectural marketing capabilities}

A competitor orientation enables organizations to determine, evaluate and respond to competitors' strengths and weaknesses (Slater \& Narver, 1990). Competitor-oriented companies track the actions of their competitors 
and emulate their products by making additional innovations to their own products and services (Lukas \& Ferrell, 2000). A market-orientation culture will affect a company's marketing capabilities, especially the planning and implementation of its marketing mix (O'Cass, Ngo, \& Siahtiri, 2012). Architectural marketing capabilities can be developed through comprehensive marketing planning based on environmental analysis and competitor information (Hamdani et al., 2018). Companies that understand their competitors' strengths and weaknesses and track their actions and strategies early will be better prepared to design their own marketing activities. Therefore, a company's ability to understand its competitors' strengths and weaknesses and to track their strategies enables it to improve its own ability to plan and implement its marketing initiatives.

$\mathrm{H} 2$ : There is a positive and significant relationship between $\mathrm{CO}$ and $\mathrm{AMC}$

\section{Inter-functional coordination and architectural marketing capabilities}

Inter-functional coordination shows the level of involvement of all the internal functions of the organization for sharing information and building harmonious relationships to reach its target market (Dyer, 2000; Mohsen, 2013). Inter-functional coordination is needed for sharing information in order to find ideas that are creative (Wang \& Miao, 2015). By utilizing marketing resources that are based on capabilities and knowledge and that focus primarily on decisions and marketing implementation strategies, architectural marketing capabilities form the basis of the model used for developing results-oriented marketing (Hamdani et al., 2018). Marketing capabilities also include collective skills, the accumulation of knowledge, and the ability to coordinate marketing activities and develop them so they become company assets. The ability to plan marketing is related to the ability to develop appropriate marketing strategies, which is achieved by aligning resources to match market conditions, thus making it easier to reach company goals (Mokwa, McKee, Varadarajan, \& Conant, 1992). Companies that achieve harmonious interfunctional coordination will facilitate the sharing of information and resources for seizing market opportunities. Harmonious inter-functional coordination, therefore, enables companies to improve their ability to plan and to implement their marketing initiatives.

$\mathrm{H}_{3}$ : There is a positive and significant relationship between IC and AMC

\section{Customer orientation and business performance}

According to Slater \& Narver (1990), customer orientation, competitor orientation and inter-functional coordination as the components of market orientation can be used to create superior value for the company. The purpose of market orientation is to provide customers with added value based on their input and analysis of the competitors (Avlonitis \& Giannopoulos, 2012). Customer orientation, in particular, plays a large role in supporting improvements in business performance (Asomaning \& Abdulai, 2015; Feng, Wang, Lawton, \& Luo, 2019; Neneh, 2018; Ogbonna \& Ogwo, 2013; Suliyanto \& Rahab, 2012) and financial performance (Taofik, Halim, \& Ibrahim, 2018). The ability to understand customers' needs and demands and create the best value for customers will better equip the company for dealing with environmental changes. Therefore, the company's ability to meet customer expectations has the potential for increasing sales and profits, and customer and capital growth.

$\mathrm{H}_{4}$ : There is a positive and significant relationship between CSO and BP 


\section{Competitor orientation and business performance}

Market information is used by companies as a guide for planning marketing to suit environmental changes (Day, 1994). A company's performance is strongly influenced by its competitor orientation; the company's ability to understand competitors' strengths and weaknesses, and their strategies and tactics (Chin, Lo, \& Ramayah, 2013; Suliyanto \& Rahab, 2012; Wang, Chen, \& Chen, 2012). The speed of responding to competitors' actions and offering new and better products has the potential to increase sales and profits, so that competitor orientation can be a determinant of financial performance. (Taofik et al., 2018). Companies that understand their competitors' strengths and weaknesses and know their strategies and actions will be able to respond quickly. Therefore, speed in understanding and responding to competitors' strategies enables companies to formulate new policies in a better way and potentially improve their business performance.

$\mathrm{H}_{5}$ : There is a positive and significant relationship between $\mathrm{CO}$ and $\mathrm{BP}$

\section{Inter-functional coordination and business performance}

According to Kanovska and Tomaskova (2012), inter-functional coordination is a process by which all internal functions are harmonized. Organizations that want to beat the competition, therefore, must be able to integrate their functions in an optimal way. Inter-functional coordination is a component that can support organizational survival (Ajay \& Jaworski, 1990). This coordination component in an organization includes the level of involvement, the quality of information and harmonious relationships across functions (Mohsen, 2013). Namusonge (2017) showed that inter-functional coordination bears a strong relationship with business performance and can produce new product leaders who will improve company performance. Harmonious inter-functional coordination makes it easy for a company to share resources and information in order to seize those market opportunities that the company has targeted. Therefore, inter-functional coordination that is used to reach the target market has the potential to improve business performance.

H6: There is a positive and significant relationship between IC and BP

\section{Architectural marketing capabilities and business performance}

Empirically and theoretically, marketing capabilities can improve a firm's performance (Morgan, 2012), while the development of architectural marketing capabilities can directly improve a firm's performance (Hamdani et al., 2018; Seifi \& Dalvi, 2014). Architectural marketing capabilities are needed for identifying the strength of the available resources so that the company can formulate a strategic plan for implementing appropriate marketing initiatives that will have an impact on improving the firm's performance and lead to sustainable growth (Hamdani et al., 2018). Likewise, architectural organizational capabilities can determine the success of a company (Chikwe, Biriowu, \& Harcourt, 2018). Architectural marketing capabilities are also needed to identify the strength of a company's resources so that it can prepare its marketing plans and implement them appropriately. The ability to explore the potential of a company's marketing resources will provide support when it is designing its marketing initiatives. Hence, the set of skills that are arranged to take advantage of a company's marketing capabilities will have the potential to improve business performance.

$\mathrm{H}_{7}$ : There is a positive and significant relationship between AMC and BP 
The concept of developing a model for testing hypotheses is shown in Figure 1.

Figure 1. Conceptual framework

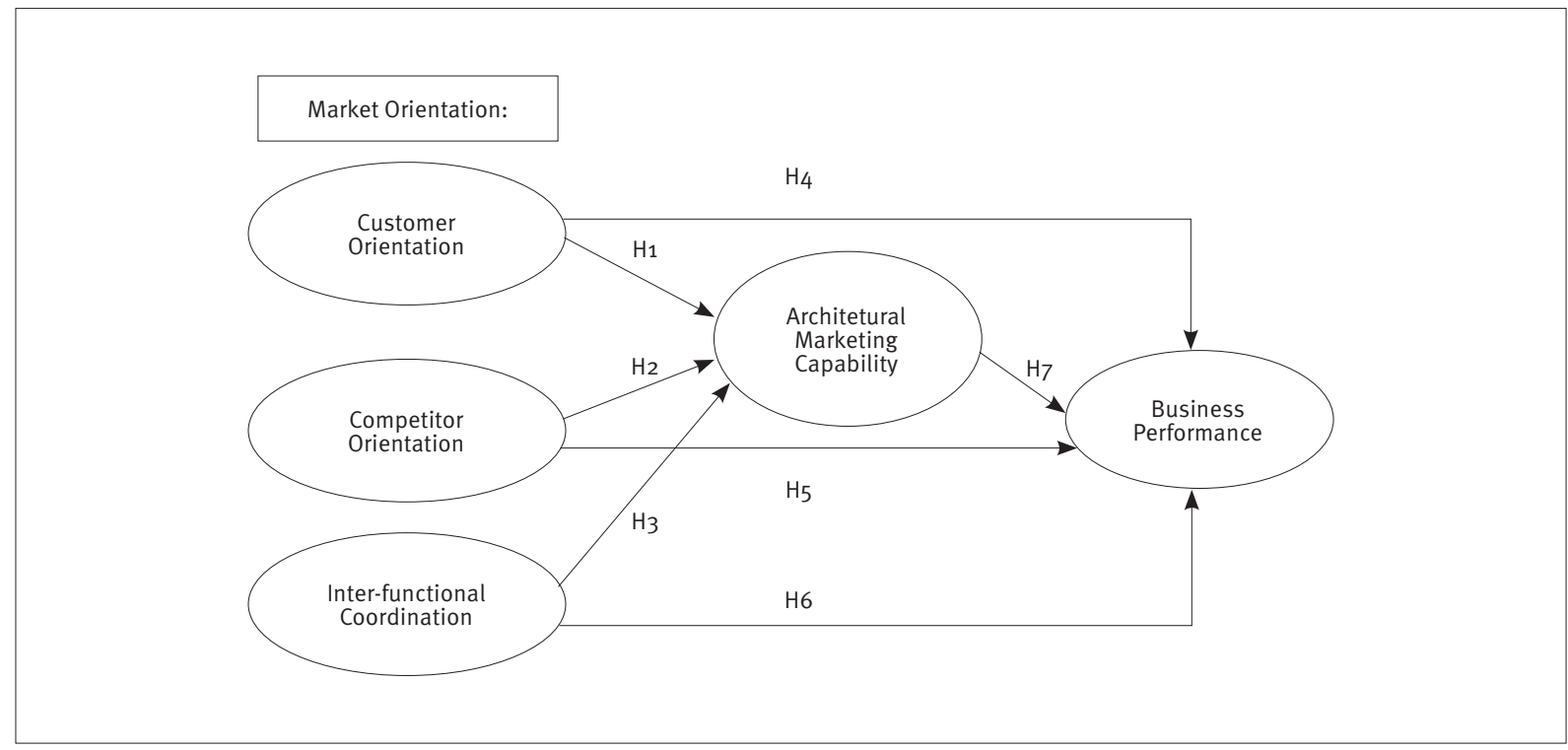

\section{RESEARCH METHOD}

\section{Data collection and the sample}

This research was conducted with small and medium-sized enterprises located in Central Java, Indonesia. The data were taken from questionnaires and interviews to ensure the accuracy of the respondents' answers. Questionnaires were distributed to 483 respondents in 12 cities/districts in Central Java Province. Central Java was selected as the sample because it makes a significant contribution to economic development in Indonesia. After selection and validation, 358 respondents met the research requirements. The sample comprises $67.3 \%$ women and $32.7 \%$ men aged between 20 and 65 years old, who have business experience that ranges between 4 and 41 years. Of the business sectors involved, $45.5 \%$ are in fashion, $22.4 \%$ in shoes, $19.6 \%$ in bags, and $12.5 \%$ in accessories. To test the potential effects of the common method, Harman's single factor test was carried out using an SPSS program. The test results show that the single factor can explain $33.4 \%$ of the total variance and is below the cut-off value of $50 \%$ (Podsakoff, MacKenzie, \& Podsakoff, 2012). Therefore, this value meets the requirements specified in the common method bias test.

\section{Measurements}

This study used primary data that were collected by researchers by way of a survey. The questionnaire was designed to measure the respondents' answers to all constructs using a rating scale of 1 - 10 (Hair, 2010). The score level allows respondents to choose from the lowest score (1) to the highest score (10). All constructs were measured using a score of 1 for "Strongly disagree" and 10 for "Strongly agree". The scale is used to 
measure research variables which include architectural marketing capabilities, customer orientation, competitor orientation, inter-functional coordination, and business performance. Measurement of the constructs in this study was taken from available literature, with some modifications being made to fit the research context. Customer orientation is adapted from Asikhia (2014) and Suleiman and Agti (2011), who measured using the indicators of consumer satisfaction, understanding consumer needs, creating value-added products for consumers, and providing after-sales service. Competitor orientation, which was adapted from Asikhia (2014) and Suleiman and Agti (2011), is measured using indicators of responding quickly to competitors' actions, creating superior products, responding quickly to changes in competitor prices, and monitoring competitors' marketing efforts. Inter-functional coordination is adapted from Asikhia (2014) and Suleiman and Agti (2011), who measured using indicators of teamwork serving customers, sharing information, cooperation for responding to competitors' actions, cooperation for formulating strategy, and cooperation for creating superior products. Architectural marketing capabilities are adapted from Trez and Luce (2012) and Vorhies and Morgan, (2005), who measured using indicators of skills in market planning, developing creative marketing strategies, accuracy in choosing target markets, allocating marketing resources effectively, turning marketing strategies into actions, and pursuing a marketing strategy appropriately. Business performance is adapted from the view of Morgan (2012) and Nuryakin et al. (2018), who measured by way of five indicators; sales growth, customer growth, sales area expansion, increased profits, and growth in business capital.

\section{Data analysis and measurement models}

The structural equation modelling (SEM) approach will be used to process the collected data and facilitate the testing of the hypotheses. The purpose of this study is to examine the relationship between customer orientation, competitor orientation, inter-functional coordination, architectural marketing capabilities and business performance. The goodness-of-fit index was used for evaluating the suitability of the recommended SEM model, including: Chi-square statistics; normal fit index (NFI); comparative fit index (CFI); Tucker-Lewis Index (TLI); and root mean square error of approximation (RMSEA).

\section{Table 1. Confirmatory factor analysis results for the measurement models}

\begin{tabular}{l|c}
\hline Variable and Indicator & Loading factor \\
\hline Customers Orientation & .696 \\
\hline Our business strategy is directed towards achieving customer satisfaction & .721 \\
\hline We strive to gain a competitive advantage based on understanding customer needs & .722 \\
\hline We develop strategies to create value-added products for customers & .705 \\
\hline We attach great importance to after-sales service & .690 \\
\hline Competitors Orientation & .752 \\
\hline We respond quickly to competitors' actions that threaten the company's development. & .677 \\
\hline We create products that are better than competitors' products & .703 \\
\hline We respond quickly to changes in prices of major competitors in the business & \\
\hline We regularly monitor the marketing efforts of major competitors & \\
\hline
\end{tabular}


Table 1. Confirmatory factor analysis results for the measurement models

Concludes

\begin{tabular}{|c|c|}
\hline Variable and Indicator & Loading factor \\
\hline \multicolumn{2}{|l|}{ Inter-functional coordination } \\
\hline We and employees work together in teams to serve customers & .684 \\
\hline We and employees share information about competitors' strengths and weaknesses & .799 \\
\hline We and employees work together to respond to competitors' actions quickly & .724 \\
\hline We and employees work together to formulate a strategy to deal with competitors & .676 \\
\hline All employees work together to create superior products according to customer desires & .680 \\
\hline \multicolumn{2}{|l|}{ Architectural Marketing Capability } \\
\hline Our skills in developing marketing planning continue to improve & .753 \\
\hline Our ability to develop creative marketing strategies continues to increase & .675 \\
\hline Our ability to segment and target markets continues to increase & .657 \\
\hline Our ability to allocate effective marketing resources continues to increase & .796 \\
\hline Our ability to interpret marketing strategies into actions continues to increase & .744 \\
\hline Our ability to execute marketing strategies quickly continues to increase & .736 \\
\hline \multicolumn{2}{|l|}{ Business Performance } \\
\hline The sales of our company have continued to increase over the past three years & .764 \\
\hline The number of our customers has continued to increase over the past three years & .741 \\
\hline Our company's sales territory has continued to increase over the past three years & .716 \\
\hline The profits of our company have continued to increase over the past three years & .675 \\
\hline The capital of our company has continued to increase over the past three years & .741 \\
\hline
\end{tabular}

Table 1 shows that all indicators are valid, which is proved by the loading factor value $>0.5$ and $p<0.05$. Table 2 shows that all indicators of the latent variables that were measured have internal consistency, meaning that all constructs are reliable (Hair, 2010). Reliability values (CR) > 0.6; Variance Extracted (VE) > 0.5, are in accordance with internal consistency standards for indicators that are being measured. The Customer orientation, Competitor Orientation, Inter-functional Coordination, Architectural Marketing Capabilities, and Business Performance variables have $C R$ values > 0.7 and $A V E>0.5$.

Table 2. Construct reliabilities, correlations, and AVE

\begin{tabular}{|c|c|c|c|c|c|}
\hline$N=358$ & 1 & 2 & 3 & 4 & 5 \\
\hline Customer Orientation (CSO) & .808 & & & & \\
\hline Competitor Orientation (CO) & .438 & .797 & & & \\
\hline Inter-functional Coordination (IC) & .546 & .532 & .871 & & \\
\hline Architectural Marketing Capability (AMC) & .519 & .499 & .500 & .871 & \\
\hline Business Performance (BP) & .523 & .513 & .525 & .552 & .858 \\
\hline Average Variance Extracted (AVE) & .679 & .797 & .871 & .781 & .770 \\
\hline
\end{tabular}




\section{RESULT AND ANALYSIS}

Testing the model using the SEM approach requires several criteria to be met, namely that the Goodness-of-Fit index was in accordance with the criteria recommended by SEM. The Chi Square value $=271.016$ and is not significant at a: 0.05, AGFI: 0.928; GFI index: 0.942; TLI: 0.991; CFI: 0.992; NFI: 928. All values meet the recommended SEM requirements, which is $\geq 0.90$. RMSEA value: 0.018 less than 0.08 and CMIN / DF 1.115 less than 2.00. Thus, the results from testing the Goodness-of-Fit index are in accordance with the recommended SEM. Therefore, the model fits, or is feasible for testing relationships between the constructs.

\section{Table 3. Hypothesis testing}

\begin{tabular}{|c|c|c|c|c|}
\hline Relationship Specifications & Std. $\beta$ & Unstd $\beta$ & SE & C. R. \\
\hline $\mathrm{H}_{1}: \mathrm{CSO} \rightarrow \mathrm{AMC}$ & .202 & .245 & .094 & $2.611^{*}$ \\
\hline $\mathrm{H}_{2}: \mathrm{CO} \rightarrow \mathrm{AMC}$ & .293 & .311 & .078 & $4.004^{\star}$ \\
\hline $\mathrm{H}_{3}: I C \rightarrow A M C$ & .265 & .269 & .069 & $3.893^{\star}$ \\
\hline $\mathrm{H}_{4}: \mathrm{CSO} \rightarrow \mathrm{BP}$ & .181 & .226 & .095 & $2.385^{\star}$ \\
\hline $\mathrm{H}_{5}: \mathrm{CO} \rightarrow \mathrm{BP}$ & .203 & .223 & .081 & $2.738^{\star}$ \\
\hline$H 6: I C \rightarrow B P$ & .202 & .212 & .073 & $2.920^{\star}$ \\
\hline $\mathrm{H}_{7}: \mathrm{AMC}->\mathrm{BP}$ & .255 & .263 & .071 & $3.688^{\star}$ \\
\hline
\end{tabular}

Note: ${ }^{*} p<0.01$

Figure 1 and Table 3 shows that there is a significant relationship between CSO and AMC (Std. $\beta=.202$, CR $=2,611, p<0.01$ ), thus $\mathrm{H}_{1}$ is accepted. Furthermore, there is a significant relationship between $\mathrm{CO}$ and AMC (Std. $\beta$ $=.293, \mathrm{CR}=4,004, \mathrm{p}$ <0.01), IC and AMC (Std. $\beta=.265, \mathrm{CR}=3,893, \mathrm{p}<0.01$ ), hence $\mathrm{H} 2$ and $\mathrm{H}_{3}$ are accepted. There is a significant relationship between CSO and BP (Std. $\beta=.181, C R=2,385, p<0.01), C O$ and BP (Std. $\beta=.203$, $C R=2,738, p<0.01$ ), IC and BP (Std. $\beta=.202, C R=2.90, p<0.01$ ), thus $\mathrm{H}_{4}, \mathrm{H}_{5}, \mathrm{H} 6$ are accepted. There is also a significant relationship between AMC and $B P(S t d . \beta=.255, C R=3.688, p<0.01$ ), which means that $\mathrm{H} 7$ is accepted.

$A M C$ as an intervening variable meets the criteria that $I C, O C$ and $C S O$ have a significant effect on $B P$, and also IC, OC and CSO have a significant effect on AMC, so then IC, OC and CSO have a significant effect on BP by controlling IC, OC and CSO (Baron \& Kenny, 1986). The results of this study show that there is a significant and decreasing influence of IC, OC, and CSO on BP when AMC is included, so there is partial mediation.

In order to test whether AMC becomes a mediating variable, this study used the Sobel test approach. From the test results, this shows that AMC is a mediating variable between CSO and BP; the effect of CSO on AMC has Unstd. $\beta=.245, \mathrm{SE}=0.094$ and $A M C$ on $B P$ has Unstd. $\beta=.263, \mathrm{SE}=0.071$. The results of the Sobel test statistic $=2.131 ; \mathrm{p}<0.05$, meaning that AMC acts as a mediating variable between CSO and BP. Test results also show that $A M C$ becomes a mediating variable between $C O$ and $B P$. The effect of $C O$ on $A M C$ has Unstd. $\beta=.311, S E=0.078$ and AMC on BP has Unstd. $\beta=.263$, SE $=0.071$. The Sobel test result statistic $=2.713 ; p<0.05$, so AMC acts as a mediating variable between $\mathrm{CO}$ and $\mathrm{BP}$. The test results show that $\mathrm{AMC}$ becomes a mediating variable between IC and BP. The effect of IC on AMC has Unstd. $\beta=.269, \mathrm{SE}=0.069$ and $A M C$ on BP has Unstd. $\beta=.263, \mathrm{SE}=0.071$. The results of the Sobel test statistic $=2.685 ; p<0.05$, meaning that AMC acts as a mediating variable between $\mathrm{IC}$ and BP. 


\section{Figure 2. Full structural model}

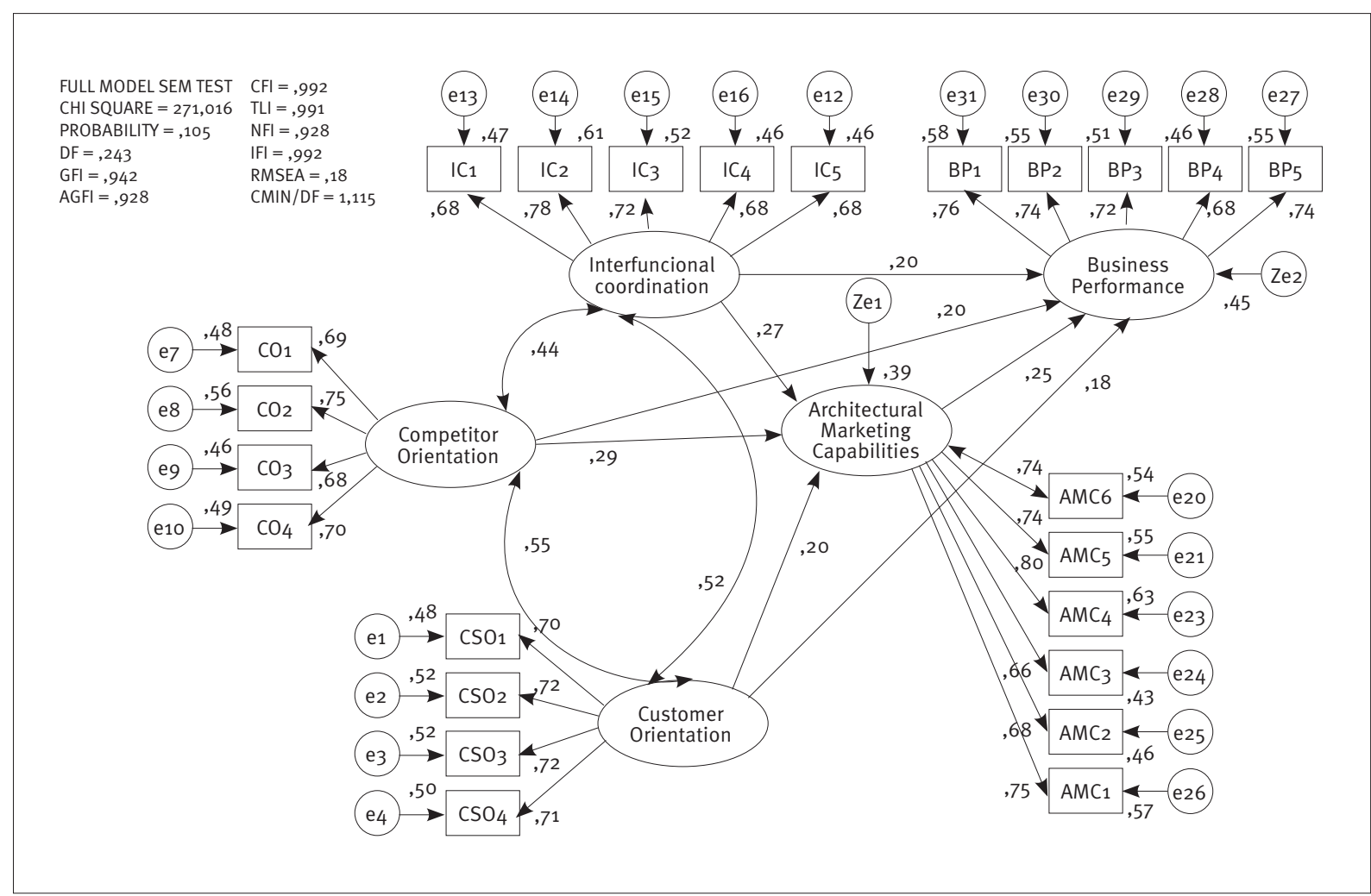

\section{DISCUSSION}

Customer orientation has a significant relationship with architectural marketing capabilities. The ability to meet and satisfy the needs of customers will facilitate marketing plan and marketing implementation programs. The results of this study are in line with the findings that market information knowledge can guide companies so they make marketing plans that are in harmony with environmental changes (Moorman \& Slotegraaf, 1999). The success of marketing products that are in accordance with customer expectations is determined by marketing strategies and the ability to implement them (Day \& Wensley, 1988). SMEs that understand their customers' needs and desires will find it easy to make plans and implement marketing programs for customer satisfaction.

Competitor orientation has a significant relationship with architectural marketing capabilities. The ability to understand the strengths and weaknesses of competitors and their strategies will guide marketing planning and marketing implementation strategies. The results of this study are in line with the findings that market orientation can improve marketing capabilities by prioritizing marketing planning and marketing implementation programs (O'Cass et al., 2012). The ability of SMEs to monitor the activities of competitors will make it easier for them to plan and put into effect their marketing programs.

Inter-functional coordination has a significant relationship with architectural marketing capabilities. A harmonious relationship between functions makes it easy to share resources, thus enabling companies to easily plan and implement their marketing strategies. These results are in line with the findings that the involvement 
of all the internal functions of the organization, information sharing, and harmonious relationships between functions, will enable companies to reach their target markets easily (Dyer, 2000; Mohsen, 2013; Song, Parry, \& Ferna, 2010). Good coordination between functions will increase the ability of SME leaders to plan and put into effect their marketing programs.

Customer orientation has a significant relationship with business performance. Meeting the needs of customers will spur companies on to innovate products that can provide value-added and the best service, thereby increasing their sales figures. Increasing their sales figures has the potential to increase business performance. This is in line with the results of research that show that customer orientation has a large role to play in supporting improvements in business performance (Asomaning \& Abdulai, 2015; Feng et al., 2019; Neneh, 2018). The ability to understand customers will determine the success of SMEs.

Competitor orientation has a significant relationship with business performance. Competitor orientation also facilitates marketing planning and implementation that are aligned with the changing needs of the target market, thus potentially increasing business performance. This is supported by the finding that understanding competitors' strengths and weaknesses, knowing their strategies and actions, and being able to respond quickly to their actions have an effect on business performance (Chin et al., 2013). SMEs that can properly monitor competitors' activities can respond quickly to them and this becomes a determinant of business performance.

Inter-functional coordination has a significant relationship with business performance. The ability to integrate all the internal functions of an organization will make it easier to share resources in order to create value-added for the target market. Companies that want to beat the competition and improve business performance must be able to integrate all the internal functions of the company. This is in line with the finding that inter-functional coordination has a strong relationship with business performance (Namusonge, 2017; Suliyanto \& Rahab, 2012). Good collaboration between functions in the organization will determine business performance.

Architectural marketing capabilities have a significant relationship with business performance. A company needs to have an effective marketing planning and implementation strategy to meet its customers' needs. Proper marketing planning and implementation will have an impact on business performance and company growth. This is supported by the finding that organizational capabilities' architecture has an influence on company success (Chikwe et al., 2018) and architectural marketing capabilities have a relationship with business performance (Hamdani et al., 2018; Seifi \& Dalvi, 2014). Architectural marketing capabilities have a large role to play as a determinant of SME performance.

Architectural marketing capabilities have an important role to play in mediating the relationship between the market orientation and business performance dimensions. Companies that understand their customers' needs and how to satisfy them can respond quickly by creating products and services that meet their customers' wishes. The company's ability to understand customer needs and how to satisfy them will facilitate marketing planning and implementation strategies, which will ultimately have an impact on business performance. Likewise, companies that know their competitors' strengths and weaknesses will be able to respond quickly to competitors' actions. Competitor orientation will facilitate marketing planning and implementation that suits the needs of the target market and provides the company with the potential to improve its business performance. The company's ability to coordinate all the internal functions of the organization will make it easier to share information and resources, and collaborate in formulating strategies for creating value-added for customers. Harmonious inter-functional coordination will facilitate marketing planning and implementation strategies, thus affecting business performance. 


\section{CONCLUSION AND IMPLICATIONS}

Improving the business performance of small and medium-sized enterprises requires the design of architectural marketing capabilities. A market orientation culture in the form of behavior, such as customer orientation, competitor orientation, and inter-functional coordination will be the foundation on which architectural marketing capabilities can be developed that have the potential to improve business performance. Customer orientation is expected to be able to understand the target market over time in order to create customer value. The company's ability to understand customers will make it easier to meet customer needs and create value for customers. The increase in the number of customers will improve business performance. Competitor orientation is expected to obtain information about the main competitors and the potential competitors and to understand their strengths and weaknesses. Competitors can be understood by monitoring their marketing efforts, creating products that are better than theirs, responding to changes in their prices and responding quickly to their activities, which will lead to the realization of an effective and efficient architectural marketing that can have an influence on improving business performance. Inter-functional coordination is needed to integrate all the internal functions of the organization in order to facilitate coordination, and share information and resources to create value-added for the target market. Inter-functional coordination, which involves building teamwork, sharing information, collaborating in the creation of products that are better than those of the competitors, and formulating joint strategies for dealing with competitors, will lead to the realization of good architectural marketing for improving business performance.

In terms of managerial implications, SMEs that are trying to improve business performance should understand customer needs, competitors' strengths and weaknesses and good inter-functional coordination in order to design appropriate marketing strategies. Leaders must understand market changes so as to create architectural marketing designs that are appropriate to their target market. An architectural marketing capability is needed so that companies can re-arrange their marketing resources and information systems. Thus, companies have the opportunity to design, formulate, and implement marketing strategies appropriately. The results of this study are expected to contribute to the development of knowledge, especially in the field of marketing information systems and architectural marketing.

\section{LIMITATIONS AND FUTURE RESEARCH}

Study of SMEs, which have limited resources, requires special attention. A market orientation culture must be developed to design effective and efficient architectural marketing. The discussion of architectural marketing in this research still focuses on marketing planning and marketing implementation. Therefore, future research can add market information management as an architectural marketing component to be implemented in large companies. Thus, a more comprehensive approach to architectural marketing will be obtained and this will contribute to the development of the science of marketing management.

\section{REFERENCES}

Ajay K. K., \& Jaworski, B. J. (1993). Market orientation: Antecendent and consequances. Journal of Marketing, 57(3), 53-70. doi:10.2307/1251854

Asikhia, 0. (2014). Customer orientation and firm performance among Nigerian small and medium scale businesses. International Journal of Marketing Studies, 2(1), 197-212. doi:10.5539/ijms.v2n1p197
Asomaning, R., \& Abdulai, A. (2015). An empirical evidence of the market orientation: Market performance relationship in Ghanaian small businesses. Educational Research International, 4(2), 69-86.

Avlonitis, G. J., \& Giannopoulos, A. A. (2012). Balanced market orientation: Qualitative findings on a fragile equilibrium. Managing Service Quality, 22(6), 565-579. doi: $10.1108 / 09604521211287543$ 
Aziz, N. A., \& Yasin, N. M. (2014). How will market orientation and external environmnet influence the performance among SMEs in the agri-food sector in Malaysia? International Business Research, 3(3), 154. doi: 10.5539/ibr.v3n3p154

Barney, J. (1991). Firm resources and sustained competitive advantage. Journal of Management, 17(1), 99-120. doi: 10.1177/014920639101700108

Baron, R. M., \& Kenny, D. A. (1986). The moderator-mediator variable distinction in social psychological research: Conceptual, strategic, and statistical considerations. Journal of Personality and Social Psychology, 51(6), 1173-1182. doi: 10.1037/0022-3514.51.6.1173

Capron, L., \& Hulland, J. (1999). Redeployment of brands, sales forces, and general marketing management expertise following horizontal acquisitions: A resource-based view. Journal of Marketing, 63(2), 41-54. doi: 10.2307/1251944

Chikwe, J. E., Biriowu, S. C., \& Harcourt, P. (2018). Organizational capabilities architecture: The drivers areas sustainable hospotolity firms in South Nigeria. Ceka International Journal of Finance \& Management Sciences, 5(2), 1-11.

Chin, C. H., Lo, M. C., \& Ramayah, T. (2013). Market orientation and organizational performance: The moderating role of service quality. SAGE Open, 3(4), 1-14. doi: $10.1177 / 2158244013512664$

Cho, H. J., \& Pucik, V. (2005). Relationship between innovativeness, quality, growth, profitability, and market value. Strategic Management Journal, 26(6), 555-575. doi: $10.1002 / \mathrm{smj} .461$

Davcik, N. S., \& Sharma, P. (2016). Marketing resources, performance, and competitive advantage: A review and future research directions. Journal of Business Research, 69(12), 5547-5552. doi: 10.1016/j.jbusres.2016.04.169

Day, G. S. (1994). The capabilities of market-driven organizations. Journal of Marketing, 58(4), 37-52. https:// doi: 10.1177/002224299405800404

Day, G. S., \& Wensley, R. (1988). Assessing advantage: for framework diagnosing superiority competitive. Journal of Marketing, 52(2), 1-20. doi: 10.1177/002224298805200201

Dubihlela, J., \& Sandada, M. (2014). Impact of strategic planning on small and medium-sized enterprises' (SMEs) performance: The role of employee participation, implementation incentives and evaluation and control. Journal of Economics, 5(1), 45-55. doi: $10.1080 / 09765239.2014 .11884983$

Feng, T., Wang, D., Lawton, A., \& Luo, B. N. (2019, July). Customer orientation and firm performance: The joint moderating effects of ethical leadership and competitive intensity. Journal of Business Research, 100, 111-121. doi: 10.1016/j. jbusres.2019.03.021

Foumani, S. A., \& Chirani, E. (2012). Marketing knowledge management in business organizations. Arabian Journal of Business and Management Review, 1(1), 44-49. doi: $10.12816 / 0003608$
Galunic, D. C., \& Rodan, S. (1998). Resource recombinations in the firm: Knowledge structures and the potential for schumpeterian innovation. Strategic Management Journal, 19(12), 1193-1201. doi: 10.1002/(SICI)10970266(1998120)19:12«1193::AID-SMJ5’3.0.CO;2-F

Gholami, S., \& Birjandi, M. (2016). The effect of market orientation and entrepreneurial orientation on the performance of SMES Journal of Current Research in Science, 1(5), 361-369. doi: 10.1016/j.jbusvent.2006.05.003

Hair, J. F., Black, W. C., Babin, B. J., \& Anderson, R. E. (2010). Multivariate data analysis (7th ed.). New York, USA: Prentice Hall.

Hamdani, N. A., Susanto, T., \& Maulani, G. A. F. (2018). Framework of architectural marketing capabilities in regional development bank. International Journal of Engineering \& Technology, 7(3.25), 166-169. doi: 10.14419/ijet.v7i3.25.17539

Han, J. K., Kim, N., Han, J. K., Kim, N., \& Srivastava, R. K. (1998, October). Market orientation and organizational performance: Is innovation a missing link? Journal of Marketing, 62(4), 3045. doi: 10.1177/002224299806200403

Henderson, R. M., \& Clark, K. B. (1990). Architectural innovation: The reconfiguration of existing product technologies and the failure of established firms. Administrative Science Quarterly, 35(1), 1-9. doi: 10.2307/2393549

Herman, H., Hady, H., \& Arafah, W. (2018). The influence of market orientation and product innovation on the competitive advantage and its implication toward small and medium enterprises (UKM) performance. International Journal of Science and Engineering Invention, 4(8), 8-21. doi: 10.23958/ ijsei/volo4-io8/02

Ho, K. L. P., Nguyen, C. N., Adhikari, R., Miles, M. P., \& Bonney, L. (2018). Exploring market orientation, innovation, and financial performance in agricultural value chains in emerging economies. Journal of Innovation \& Knowledge, 3(3), 154-163. doi: 10.1016/j.jik.2017.03.008

Hwang, Y. I., \& Chung, S. (2018). Market orientation, social responsibility, and performance in Korea's healthcare industry. International Journal of Healthcare Management, 11(4), 325-332. doi: 10.1080/20479700.2017.1404728

Idrus, S. Al, Ahmar, A. S., \& Abdussakir, A. (May, 2018). Contribution of organizational learning and market orientation on business unit performance mediated by job satisfaction at dairy cattle milk cooperatives in East Java, Indonesia. Journal of Reviews on Global Economics, 7, 207-216. doi: 10.6000/1929-7092.2018.07.19

Javidan, M. (1998). Core competence: What does it mean in practice? Long Range Planning, 31(1), 60-71. doi: 10.1016/ soo24-6301(97)0oo91-5

Kanovska, L., \& Tomaskova,E. (2012). Interfunctional coordination at hi-tech firms. Enzinerine Ekonomika-Enginering Economic, 23(1), 70-76. doi: 10.5755/jo1.ee.23.1.1224

Kaswuri, A.H., Ramayah, M. A., \& Aldakhil, T. A. M.. (2017). The effect of market orientation as a mediating variable in the relationship between entrepreneurial orientation and SMES performance. Nankai Business Review International, 8(4), 404-423. doi: 10.1108/NBRI-10-2016-0035 
Kharabsheh, R., Jarrar, K., \& Simenonva, B. (2014). The impact of competitive strategies on responsive market orientation, proactive market orientation, learning orientation and organizational performance. Journal of Strategic Marketing, 23(5), 1-13. https://doi 10.1080/0965254X.2014.970217

Jaworski, B. J., \& Kohli, A. K. (1993). Market orientation: Antecendents and consequences. Journal of Marketing, 57(3), 53-70. doi:10.2307/1251854

Lee, Y. K., Kim, S. H., Seo, M. K., \& Hight, S. K. (2015, January). Market orientation and business performance: Evidence from franchising industry. International Journal of Hospitality Management, 44, 28-37. doi: 10.1016/j.ijhm.2014.09.008

Lukas, B. A., \& Ferrell, O. C. (2000). The effect of market orientation on product innovation. Journal of the Academy of Marketing Science, 28(2), 239-247. doi: 10.1177/0092070300282005

Mamun, A. Al, Mohiuddin, M., Fazal, S. A., \& Ahmad, G. B. (2018) Effect of entrepreneurial and market orientation on consumer engagement and performance of manufacturing SMES. Management Research Review, 41(1), 133-147. doi: 10.1108/ MRR-04-2017-0102

Micheels, E. T., \& Gow, H. R. (2008). Market orientation, innovation and entrepreneurship: An empirical examination of the Illinois beef industry. International Food and Agribusiness Management Review, 11(3), 1-26. doi: 10.22004/ ag.econ.53649

Mohsen, K. (2013, September). Enhancing Inter functional coordination and marketing performance: utilization of the motivation/ability/opportunity framework. EBS Working Papers WP2013-9, University of Essex, Colchester.

Mokwa, M. P., McKee, D. O., Varadarajan, P. P., \& Conant, J. S. (1992). Success procedur and failure preventer marketing skill: A social learning theory interpretation. Journal of the Academy of Marketing Science, 20(1), 17-26. Retrieved from http://hjb. sagepub.com.proxy.lib.umich.edu/content/9/2/183.full. pdf+html

Moorman, C., \& Slotegraaf, R. J. (1999). The contingency value of complementary capabilities in product development. Journal of Marketing Research, 36(2), 239-257. doi: 10.2307/3152096

Morgan, N. A. (2012). Marketing and business performance. Journal of the Academy of Marketing Science, 40(1), 102-119. https://doi.org/10.1007/s11747-011-0279-9

Morgan, N. A., Slotegraaf, R. J., \& Vorhies, D. W. (2009). Linking marketing capabilities with profit growth. International Journal of Research in Marketing, 26(4), 284-293. https://doi. org/10.1016/j.ijresmar.2009.06.005

Narver, J. C., \& Slater, S. F. (1990). The effect of a market orientation on business profitability. Journal of Marketing. 54(4), 20-35. doi: 10.1177/002224299005400403

Neneh, B. N. (2018). Customer orientation and SME performance: The role of networking ties. African Journal of Economic and Management Studies, 9(2), 178-196. https://doi.org/10.1108/ AJEMS-03-2017-0043
Nduriri, M. W., \& Namusonge, D. M. (2017). Market orientation, entrepreneurial orientations and performance SMEs hotel in Nanyuky Town Kenya. Europenan Journal of Business and Strategic Management, 2(1), 1-14. Retrieved from https:// www.iprjb.org/journals/index.php/EJBSM/article/view/239

Nuryakin, N., Didiek A. V., \& Budi, M. (2018). Mediating effect of value creation in the relationship between relational capabilities on business performance. Contaduría y Administración, 63(1), 1-21. doi: 10.22201/ fca.24488410e.2018.1178

O’Cass, A., Ngo, L. V., \& Siahtiri, V. (2012). Examining the marketing planning-marketing capability interface and customer-centric performance in SMEs. Journal of Strategic Marketing, 20(6), 463-481. doi: 10.1080/0965254X.2012.707675

Ogbonna, B., \& Ogwo, O. E. (2013). Market orientation and corporate performance of insurance firms in Nigeria. International Journal of Marketing Studies, 5(3), 104-116. doi: 10.5539/ijms.v5n3p104

Podsakoff, P. M., MacKenzie, S. B., \& Podsakoff, N. P. (2012). Sources of method bias in social science research and recommendations on how to control it. Annual Review of Psychology, 63(1), 539-569. doi: 10.1146/annurevpsych-120710-100452

Rahman, N. R. A., Othman, M. Z. F., Yajid, M. S. A., Rahman, S. F. A., Yaakob, A. M., Masri, R., \& Ibrahim, Z. (2018). Impact of strategic leadership on organizational performance, strategic orientation and operational strategy. Management Science Letters, 8(12), 1387-1398. doi: 10.5267/j.msl.2018.9.006

Sadikoglu, E., \& Zehir, C. (2010). Investigating the effects of innovation and employee performance on the relationship between total quality management practices and firm performance: An empirical study of Turkish firms. International Journal of Production Economics, 127(1), 13-26. doi: 10.1016/j. ijpe.2010.02.013

Seifi, R., \& Dalvi, M. R. (2014). A study of effects of specialized marketing capabilities on performance marketing unit based on Morgan et al. case: Past industry in Tehran. International Journal of Academic Research in Economics and Management Sciences, 3(1), 441-451. doi: 10.6007/ijarems/v3-i1/601

Slotegraaf, R. J., \& Dickson, P. R. (2004). The parad ox of a marketing planning capability. Journal of the Academy of Marketing Science, 32(4), 371-385. doi: 10.1177/0092070304265217

Song, M., Parry, M. E., \& Ferna, P. (2010, May). Perspective: Cross-functional integration in Spanish firms. Journal Production Innovation Management, 27, 606-615. https://doi. org/10.1111/j.1540-5885.2010.00738.x

Song, X. M., Xie, J., \& Dyer, B. (2000). Antecedents and consequences of marketing managers' conflict-handling behaviors. Journal of Marketing, 64(1), 50-65. doi: 10.1509/ jmkg.64.1.50.17989

Stam, W., Arzlanian, S., \& Elfring, T. (2014). Social capital of entrepreneurs and small firm performance: A metaanalysis of contextual and methodological moderators. Journal of Business Venturing, 29(1), 152-173. doi: 10.1016/j. jbusvent.2013.01.002 
Suleiman, A. M., \& Agti, D. A. M. (2011). The impact of internal marketing on commercial banks' market orientation. International Journal of Bank Marketing, 29(4), 308-332. doi: $10.1108 / 02652321111145943$

Suliyanto, S., \& Rahab, R. (2012). The role of market orientation and learning orientation in improving innovativeness and performance of small and medium enterprises. Asian Social Science, 8(1), 134-145. doi: 10.5539/ass.v8n1p134

Taofik, B., Halim, F., \& Ibrahim, A. (2018). The relationship between market orientation dimensions and performance of micro finance institutions. Journal of Marketing Management and Consumer Behavior, 12(3), 1-14. doi:10.24052/jbrmr/ v12iso3/art-11

Trez, G., \& Luce, F. B. (2012). Organizational structure and specialized marketing capabilities in SMEs. Marketing Intelligence and Planning, 30(2), 143-164. doi: $10.1108 / 02634501211211957$

Udriyah, U., Tham, J., \& Azam, S. (2019). The effects of market orientation and innovation on competitive advantage and business performance of textile SMEs. Management Science Letters, 9(9), 1419-1428. doi: 10.5267/j.msl.2019.5.009
Vorhies, D. W., Harker, M., \& Rao, C. P. (1999). The capabilities and performance advantages of market-driven firms. European Journal of Marketing, 33(11/12), 1171-1202. doi: 10.1108/03090569910292339

Vorhies, D. W., \& Morgan, N. A. (2003). A configuration theory assessment of marketing organization fit with business strategy and its relationship with marketing performance. Journal of Marketing, 67(1), 100-115. doi: 10.1509/ jmkg.67.1.100.18588

Vorhies, D. W., \& Morgan, N. A. (2005). Benchmarking marketing capabilities for sustainable competitive advantage. Journal of Marketing, 69(1), 80-94. doi: 10.1509/jmkg.69.1.80.55505

Wang, C., Chen, K., \& Chen, S. (2012). Total quality management, market orientation and hotel performance: The moderating effects of external environmental factors. International Journal of Hospitality Management, 31(1), 119-129. doi: 10.1016/j. ijhm.2011.03.013

Wang, G., \& Miao, C. F. (2015). Effects of sales force market orientation on creativity, innovation implementation, and sales performance. Journal of Business Research, 68(11), 2374-2382. doi: 10.1016/j.jbusres.2015.03.041

\section{AUTHORS' CONTRIBUTION}

Mulyana Mulyana worked on the conceptualization and theoretical-methodological approach. The theoretical review was conducted by Zainuddin Zakaria. Data collection was coordinated by Rosman Mahmood. Data analysis included Mulyana Mulyana, Zainuddin Zakaria, and Rosman Mahmood. All authors worked together in the writing and final revision of the manuscript. 